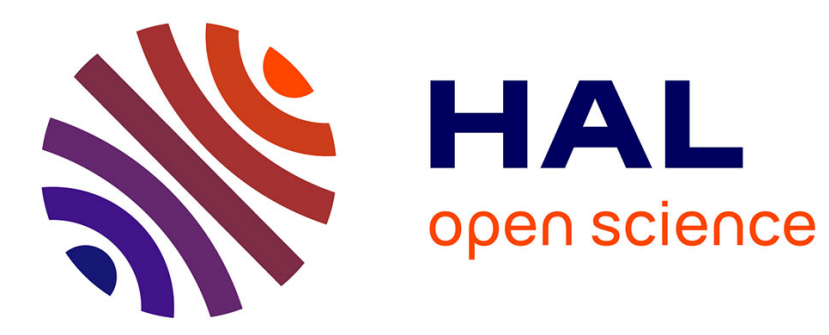

\title{
Non-Euclidean geometry and political economy How Jacques Rueff explained unemployment in England (1919-1931)
}

\author{
Adrien Lutz
}

\section{- To cite this version:}

Adrien Lutz. Non-Euclidean geometry and political economy How Jacques Rueff explained unemployment in England (1919-1931). 2015. halshs-01199259

\section{HAL Id: halshs-01199259 \\ https://shs.hal.science/halshs-01199259}

Preprint submitted on 15 Sep 2015

HAL is a multi-disciplinary open access archive for the deposit and dissemination of scientific research documents, whether they are published or not. The documents may come from teaching and research institutions in France or abroad, or from public or private research centers.
L'archive ouverte pluridisciplinaire HAL, est destinée au dépôt et à la diffusion de documents scientifiques de niveau recherche, publiés ou non, émanant des établissements d'enseignement et de recherche français ou étrangers, des laboratoires publics ou privés. 


\title{
GATE $_{\text {vossentromex }}$
}

UMR 5824

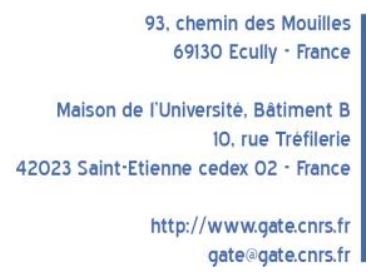

WP 1522 - September 2015

\section{Non-Euclidean geometry and political economy How Jacques Rueff explained unemployment in England (1919-1931)}

Adrien Lutz

\begin{abstract}
:
This paper provides new perspectives on the French liberal economist Jacques Rueff (18961978), especially as regards his early writings on unemployment. We aim to show that Rueff distinguishes the root causes of permanent unemployment in England (1919-1931) based upon an interesting reading of non-Euclidean geometry.

Controversially, this enables him to locate the cause of unemployment in the stickiness of the wage/price ratio. Hence, arguing that reality remains inaccessible in itself, Rueff focuses on a succession of variables (price, wage, unemployment), supplemented by his concepts of rational ego and the reasoning machine, in order to approach this reality.
\end{abstract}

\section{Keywords:}

Rueff, unemployment, real wage

JEL codes:

B13, E24, N00

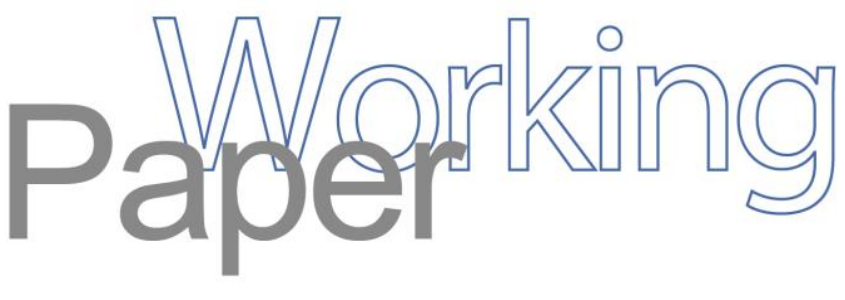




\title{
Non-Euclidean geometry and political economy How Jacques Rueff explained unemployment in England (1919-1931)
}

\begin{abstract}
This paper provides new perspectives on the French liberal economist Jacques Rueff (18961978), especially as regards his early writings on unemployment. We aim to show that Rueff distinguishes the root causes of permanent unemployment in England (1919-1931) based upon an interesting reading of non-Euclidean geometry.

Controversially, this enables him to locate the cause of unemployment in the stickiness of the wage/price ratio. Hence, arguing that reality remains inaccessible in itself, Rueff focuses on a succession of variables (price, wage, unemployment), supplemented by his concepts of rational ego and the reasoning machine, in order to approach this reality.
\end{abstract}

JEL Code: B13, E24, N00

Keywords: Rueff, unemployment, real wage

\footnotetext{
${ }^{1}$ Université de Lyon, Lyon, F-69007, France ; CNRS, GATE Lyon Saint-Etienne, Ecully, F69130, France ; Université Jean Monnet, Saint-Etienne, F-42000, France
} 


\section{Introduction}

The works of French economist Jacques Rueff (1896-1978) are well known and their importance is widely acknowledged. As indicated by his preface to Robbins's La grande dépression (1935), many famous economists of Rueff's era respected his ideas, addressing for example his views on unemployment (Beveridge 1909, Hicks 1932, Keynes 1939, Pigou 1920, 1927), money (Mundell 1973) or transfers (Keynes 1929a, b, c). More recent works on Rueff have focussed on the monetary aspects of his writings (Pays 1991, Chivvis 2010).

However, the young Rueff (pre-1939) remains largely unknown, and the use he proposed for non-Euclidean geometry in political economy has been little studied (excepting Frobert 2010). This is due to the fact that Rueff is influenced by a Cartesian method inherited from geometry to the problem of unemployment in England (Rueff 1925, 1931), which caused controversy - generally speaking, all that is recalled about this episode is that he made some proposals which seemed rather cold-blooded compared with the human disaster of unemployment. Although Rueff is respected by his peers, the anomaly remains that he is a major French economist whose early epistemological writings are very little known (see, however, Claassen 1967). Moreover, his interest in geometrical methods is widely neglected. This article remedies this neglect by providing an overview of Rueff's readings of geometry in political economy, and exploring its intellectual roots.

Rueff is strongly influenced by a metaphor based upon non-Euclidean geometry. More exactly, he adopts a particular conception of reality: only the structure of reasoning counts, regardless of whether the result is observable or not. Here he makes reference to the scientific developments in non-Euclidean geometry achieved by Carl Friedrich Gauss (1777-1855), Bernhard Riemann (1826-1866), János Bolyai (1802-1860) and Nikolai Ivanovich Lobachevsky (1792-1856). Jacques Rueff is not the only economist to have drawn on this movement to bring new perspectives to the science; but we argue here that Rueff is the only one to have been strongly influenced by this field of knowledge in order to enlighten social issues.

In this respect, the first part of this paper deals with the concept of unemployment. Here, Rueff provides a controversial analysis based upon the tools he designed, particularly the wage/price ratio. Indeed, the very way he constructed his notion of causality - based upon the difference between the level of unemployment and this famous ratio - was seen as controversial. Hence, a major consequence is that Rueff argues for a decrease in the wage/price ratio: here, then, stands a complex choice, decreasing wages while prices stay constant, or increasing prices while wages stay constant.

The second part of this paper shed light of the intellectual root of this analysis and states that the tools designed by Rueff are based upon his interest in non-Euclidean geometry, a development in mathematics which indicated that our world could be apprehended from more than three dimensions. This intellectual movement remains the first step taken by several sciences towards a new conception of reality. We also show that Rueff considers reality to be inaccessible. In his view, we only can design tools which tend to approach this reality. Hence, our rational ego and our reasoning machine - in addition to our language enable us to build knowledge in a way which leads us to understand our human condition. Rueff never places trust in our ability to find principles of causality: causes are only a human creation, a convention which helps us in our practice of science ${ }^{2}$.

\footnotetext{
${ }^{2}$ In the French edition of 1922, Rueff uses the term of "principe de causalité" which Herman Green translates as "Law of Causality" (Rueff, 1929 [1922]). We choose to keep the term "principle of causality" except in quotations from this English edition.
} 


\section{Rueff's analysis of British unemployment}

We analyse here Rueff's work as related to unemployment, published as "Les variations du chômage en Angleterre" (1925), "Chômage et salaire réel en Angleterre dans la période 19191925" (1926) and "L'assurance-chômage, cause du chômage permanent" (1931a, 1931b). ${ }^{3}$ These works contain the clearest presentation of his method. We separate our development into two key syllogistic aspects, as Rueff himself recommended: observation (4.1) and reasoning (4.2).

\subsection{The empirical branch: hypothesis and observations}

Rueff's work starts from two simple observed facts: the almost exponential increase in unemployment in England between 1919 and 1920, and the parallelism between the unemployment curve and the wage/price ratio curve. Therefore, Rueff hypothesizes, changes in unemployment are linked to the difference between levels of wages and prices. More precisely, these changes in unemployment could be explained by changes in this difference and follow the same fluctuations. Before going further, we thus present the variables unemployment, price and wage:

1. Unemployment is a rate established in relation with the unions: hence it does not strictly measure the number of individuals over 15 years of age who are without a job and who are searching for one, as it is defined today. Rather, this rate is the "percentage of workers unemployed in a number of trade unions compared with the total number of members of these unions" (1931a: 245). This percentage was commonly used at that time and doesn't aspire to pose any particular concern as regards its design or in its use. Hence, "the published indices can't give an idea of the absolute importance of unemployment, but enable us to follow the magnitude of its variations in satisfactory condition" (1925b: 426).

2. Concerning wages, Rueff reasons with real wages, which are obtained by calculating the ratio between nominal wages and prices. For nominal wages, he uses an index created by Professor Arthur L. Bowley (1869-1957), a statistician and a major figure in the introduction of descriptive statistics in political economy (few works of his time use numbers other than his own).

3. On prices, Rueff uses wholesale prices furnished by the Board of Trade: this is the monthly sum of the "price of a number of commodities and goods, chosen once and for all (45 in the index of Statistique Générale de France)" (1923a: 101). Again, this variable is commonly used and seems difficult to criticize.

The controversial element is the ratio itself. Indeed, Rueff has been criticized for using a real wage based upon wholesale prices: as Rueff argues, the goal is to analyse the "disparity between changes in wages and changes in selling prices, not the purchasing power of the worker [...] without going into considerations of fairness or fair price" (1931c: 244). Hence, what really interests Rueff is the observation of the disparity between different variables. Rueff doesn't see wages as purchasing power but as a cost of business returns, and so as a "cost of human labour per unit of output" (Ibid., 244). Rueff focuses clearly on the supply side and on changes in wages as a cost as well as the selling prices. This explains the choice of wholesale prices.

\footnotetext{
${ }^{3}$ See also the other works from Rueff on unemployment in which (with Georges Lane) he analyses English unemployment after the Second World War (from 1963 to 1975) and criticizes the Phillips's curve (see their article, "La fin de l'ère keynésienne", in Le Monde, February 19, 20 and $\left.21^{\text {th }} 1976\right)$.
} 
According to Rueff, the index of wholesale prices remains the most able to establish observations in terms of the economic equilibrium of the goods market. In fact, "we see the price index increasing with the overall average of prices, and we can say that when this index increases, the purchasing power of the monetary unit, which is used to express these studied prices, decreases in the same proportion" (1923a: 101). Indeed, this is a conception of price as a factor of economic equilibrium. A price is adequate even though it remains high, simply because it has been freely determined. In this respect, wage acts as a variable of equilibrium on the labour market. Rueff notes, therefore, several elements that constitute the empirical branch of this work and which are the basis for his reasoning (see Table 1):

It is precisely from the time when the index of wholesale prices decreases in England as unemployment rises, and it continues to increase as the wage index increases. Then the representing curve of this index is close to the prices curve, and unemployment begins to decrease, until the beginning of 1925 when it resumes its increase as the difference between the two curves grows again. (1925b: 427)

The indexes of wages $\mathrm{W}$ and prices $\mathrm{P}(\mathrm{W} / \mathrm{P}$ as a real wage) both increase until the mid-1920s with the level of variation of the price index a third higher than the wage index, all with low unemployment. Then the prices index decreases more than wages. Moreover, the decrease of prices arises earlier compared to wages (mid-1920 against mid-1921) and the wage/price ratio increases sharply, as well as unemployment. Finally, the price index continues to decline, although it remains low, while the wage index stabilizes. Unemployment only decreases by some 8.8 points before resuming its rise, while the W/P ratio also arises again. The second quarter of 1920 sees unemployment reaching its minimum (1.1\%) while the price index also reaches its maximum, where the wage is at its $5^{\text {th }}$ highest value (after the next 4 quarters). This period of growth of these two variables is symbolized by a W/P ratio at a low level (the $3^{\text {rd }}$ lowest value after the two previous quarters). Exactly one year later, the second quarter of 1922 is marked by one of the highest unemployment rates $(20.9 \%)$. It is interesting to note that, over the period, the wage index reaches its second highest value (after the next quarter), while the price reaches its $18^{\text {th }}$ highest value, giving rise to the maximum ratio wage/price (1.333).

And this is easily explained. During a monetary depreciation, it is due to the constant rise in prices that the workers are demanding an increase in their wages, and they obtain it with an obvious but significant lateness. When, for example, the price level reported to base 100 for the year 1913 reaches its maximum, i.e. 324 (more than three times the pre-war level), the level of wages reported on the same basis never exceeds 250 (two and a half times the pre-war level). Here stands a general situation that seems characteristic of all periods of rising prices. (1925b: 435)

The wage index begins to decline when unemployment reaches its maximum, while the price index begins to decrease when unemployment reaches its minimum, with unemployment ceasing to decrease from mid-1921 to mid-1924. This decrease in index continues - except for some minor variation - in the last two years when the wages decline, and where prices had already seen their rate of decline slowing significantly from 1922 . This coincides with a rise in unemployment from mid-1924. Regarding the wage/price ratio, we note that it decreases while unemployment reaches its minimum. Then it increases along with it: this seems to be due to the increase in the wage index coupled with the decrease in prices until mid-1921, and then to a lesser decrease in the wage index related to prices until the beginning of 1922. Unemployment then fluctuates downward (-19.6\%) from 1922 to 1923, and then increases $(12.2 \%)$ from 1924 to 1925 . This may be explained by the above 
observations, namely a small rise in the wage index in 1924 accompanied by a slowdown in the rate of decrease of the price index starting at the beginning of 1922.

Obviously these figures are not accurate and only approximately reflect general trends, but this does not prevent us seeing, for instance, the impact of the American crisis of 19201921: this is in part due to lower discount rates (bank rate) in the United States, intended to absorb part of the debt. The result is a decrease in prices and in economic activity that inevitably affects the English markets. Hence, these figures do not teach us much in themselves, except in so far as they are indicative of an a priori link between the wage/price ratio and unemployment. It would be naive to hope for a return to a low unemployment rate with a level of the price index a third higher than wages, as it was the case until the middle of 1920.

With his tools defined and the variations discussed, Rueff then derives a possible link between changes in unemployment and in the ratio between wages and prices. He then constructs a curve for this second ratio (see diagrams 1 and 2). What are his observations?

You just have to simultaneously consider the two curves to determine, without a doubt, the whole synchronism of their movements. In general the unemployment index varies along with the wage/price ratio except at some points (Q1 1920 Q1 1924) where changes in the first immediately follow the second. (Ibid., 429)

In his second article of 1931, Rueff notes that "a simple glance at the diagram shows clearly that what was true from 1919 to 1925 was also true from 1928 to 1931, and with as much rigor and precision as in the past" (1931a: 214). In the end, Rueff correlates the wage/price ratio and the unemployment rate. This correlation was described by Sir Josiah Stamp (1880-1941) - statistician and former director of the Bank of England from 1928 to 1941 - as particularly significant (95\%) in the Financial Times of March $15^{\text {th }} 1926$. Therefore Rueff bases his hypothesis upon the observation of general facts.

\subsection{The rational branch: Rueff's reasoning}

The hypothesis is that unemployment increases as the difference between wages and prices also increases. As prices freely fluctuate - excluding some protectionist tendencies whose incidence has little to do with the effects of unemployment insurance - questions arise concerning sticky wages. Rueff thus wonders whether wages are too high, or more precisely why wages does not play their role by stabilizing an economic equilibrium.

There is, thus, a reason to believe that the immediate cause of widespread unemployment [...] would constitute a failure of wage adjustment to the general price level. In so far as a crisis unprecedented in History rages in England, it is that lower prices are only followed by lower wages - and that after stabilization at the end of 1921, the percentage increase in wages relative to the pre-war remained too high relative to the percentage increase in price. (1925b: 432-433)

The price mechanism, which guarantees the economic equilibrium, is blocked to the extent that labour supply is higher than demand. This occurs because of an imbalance in the labour market, where the variable-price is unable to address this deficit adjustment:

The discipline of the trade unions in the first place, is extremely powerful in England, and the contract system of collective work, more widespread than elsewhere. The tradition, however, would have been insufficient to maintain the resilience of unemployed workers to the inevitable movement of wages, if a policy of subsidies to the unemployed, as generous as costly to the country, had allowed them to remain unoccupied indefinitely, rather than infringe the union instructions. (Ibid., 435-436) 
So this is due first to the role played by the unions and also by the state, which act to impede the stabilizing role of the price mechanism. Here lies the core of Rueff's reasoning: for this observation leads ultimately to the postulation of different types of unemployment linked with sticky wages:

1. The context is characterized by a cyclical decrease in prices higher than wages, "hence we see how there can exist in the lowering or increasing of prices an influence able to govern the labour market" (Ibid., 435). Rueff here joins the classical tradition regarding the interdependence of labour, monetary, goods and financial markets. To this type of unemployment is added the movements of labour as "in the month of August 1920, there were 120,000 unemployed persons in Great Britain, a quite similar figure to the pre-war figure, which seemed to respond to the inevitable movement of labour" (1926: 54). These inevitable movements of labour, as well as the movements of prices, constitute what Rueff calls temporary unemployment. This is defined as unemployment due to lower prices being absorbed by an increase in activity through lower wages.

2. There is an excessive wage compared to any equilibrium value given by the performance of work. This constitutes a classic vision of voluntary unemployment. So there would be, on Rueff"s account, inactivity traps, as "it is very curious and seemingly contrary to all economic laws, that wages could remain stable, while the labour supply also significantly exceeded labour demand" (1925b: 435). This type of unemployment is permanent in the light of previous developments: it persists since the variables of prices and wages do not freely fluctuate.

Finally, temporary unemployment isn't a problem in itself as, according to Rueff, the wages/prices ratio varies with unemployment itself. This allows a return to equilibrium: there is often unemployment in periods of decreasing prices. This unemployment is only temporary, as it is absorbed when prices rise on the condition that wages follow the trend. For Rueff, this has always been the case. But this wages/prices ratio is now blocked, or more precisely it doesn't vary appropriately: wages don't decrease quickly enough, thus establishing permanent unemployment. The problem here is not low wages:

From now, regarding wages the level wouldn't be one that would ensure the employment of all the available labour force - given the volumes of existing capital - but the resulting level from the rate of unemployment insurance, itself determined by social rather than economic considerations. Thus, in England the level of wages is found strictly immobilized. (1931c: 871)

Here he is targeting the first type of unemployment noted above. In other words, the disappointments of British economic policy are due to the fact that the lawmakers are taking into consideration factors that are not purely economic. They are dealing with social considerations that are not relevant to the problems they are seeking to tackle. Political economy should only deal with economic facts, whereas the British government is confusing economic and social views. This is the heart of the problem, as it prevents market regulation of prices and so gives birth to inactivity traps. We should also notice that unemployment is not the only problem here, as "the Bank of England has consistently tried for two years to avoid the higher interest rates that would rather result from the deficit in the balance of payments" (Ibid., 873).

Rueff takes the opportunity in his article of 1931 to attack the work of the ILO (International Labour Office), an institution which he thinks has not seen this mismatch: its analysis takes the level of prices to be the sole cause of unemployment (see Annex II of Rueff 1931a: 247-251, entitled Notes relatives aux vérifications expérimentales présentées par le Bureau International du Travail dans son étude sur "Les fluctuations monétaires et le 
chomage"). In addition, in the ILO's analysis of the causes of unemployment, it fails to deal with what restrains wages - an omission noticed by Rueff, who remarks that this report "didn't mention, at least explicitly, measures which tend to immobilize wages" (1931a: 223). The ILO isn't entirely wrong in its analysis, as it is a fact that there is much unemployment as a result of lower prices (an equivalent to Rueff's temporary unemployment), but when prices increase, unemployment doesn't decrease, since the wages/prices ratio continues to increase, as Rueff has shown. Indeed, from mid-1923 wages increase simultaneously with a decrease in prices. Hence, according to Rueff, the ILO focuses too much on the variable of price and obscures the wage/price relationship. If wages are blocked, it is normal that unemployment should vary based upon price alone, but the fact remains that it is the lack of wage adjustment which is at issue, according to Rueff.

Regarding possible solutions, Rueff doesn't consider a decrease in the dole (unemployment insurance), but rather advocates higher prices without increasing wages or lower wages without a decrease of prices. In order to avoid an impact on the entire global market, a depreciation of the British Pound or an increase tariffs appear as good solutions. Rueff proposes this second solution in his first article (1925), but only six years later it is no longer conceivable for him. This is due in part to the protectionist inclinations of England, but is also based on the observation that prices have increased without a concomitant decrease in unemployment.

Hence Rueff have designed tools in order to enlighten social issues such as unemployment. We argue that this is based upon his early readings - for instance Poincaré and his interest in non-Euclidean geometry. Indeed, this field of knowledge was in progress during his youth. In this respect we aim to present the contributions of non-Euclidean geometry that deeply influenced the young Rueff.

\section{The non-Euclidean metaphor}

\subsection{The contributions of non-Euclidean geometry}

During his youth, Rueff read Science and Hypothesis (1902) and The Value of Science (1905) by Henri Poincaré (1854-1912). He also became familiar with the geometry developed by Riemann and Lobachevsky. Established for over 2,000 years, Euclidean geometry is still taught in schools today, and is based upon five major postulates designed to demonstrate various proposals in a three-dimensional space (width, height, depth). Here is the fifth postulate:

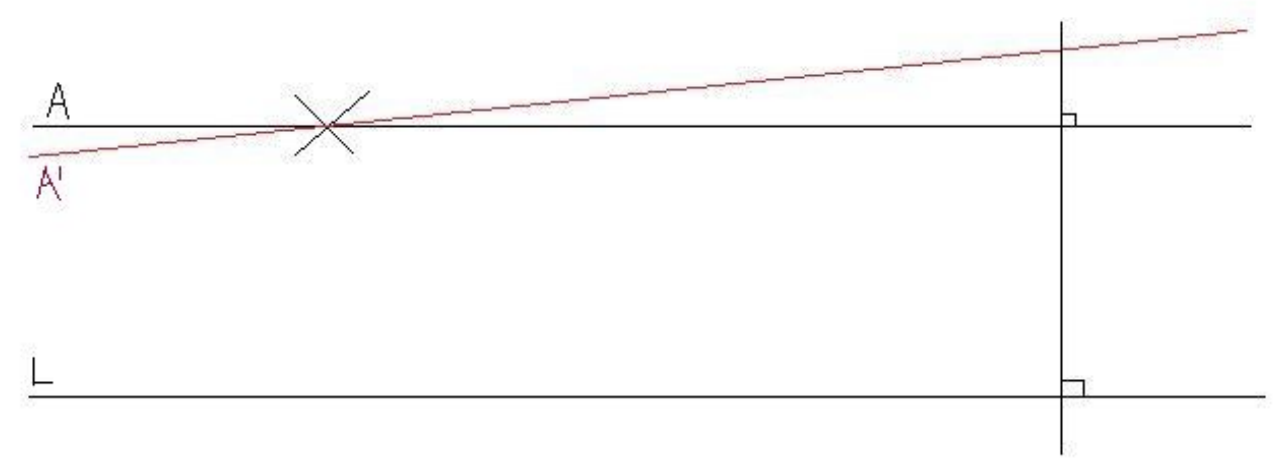

Figure $\mathbf{n}^{\circ} \mathbf{1}$ - Euclidean postulate n. 5 (the parallel postulate)

According to this postulate, for any point on a line L, there can pass only one parallel line to the given line A. Euclid originally proved it in these terms: 
And that if a straight-line falling across two (other), straight-lines makes internal angles on the same side (of itself whose sum is) less than two right-angles, then the two (other) straightlines, being produced to infinity, meet on that side (of the original straight-line) that the (sum of the internal angles) is less than two right-angles (and do not meet on the other side). (2007: 7)

During the eighteenth century, brilliant thinkers built a new geometry upon the rejection of this postulate. Although Lobachevsky, Riemann and Bolyai are most often mentioned in connection with the development of a geometry which dispenses with the fifth postulate, it was Gauss who first succeeded in opening the way to non-Euclidean geometry. His results were not published immediately, as they formed part of his correspondence with Heinrich Christian Schumacher (1757-1830) in the 1820s. Being exceptionally difficult to understand, the works of Lobachevsky and Bolyai in the years 1830-1840 remained widely unnoticed. Proper acknowledgment had to wait for more than 20 years, with the publication of the correspondence between Gauss and Schumacher and the translation of Bolyai and Lobachevsky's books into several languages.

Non-Euclidean geometry went through a significant process of development, with results provided first in a four-dimensional framework and then for $n$-dimensions, driven by famous authors such as Poincaré.

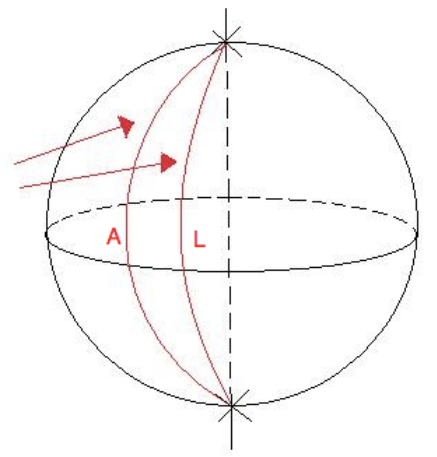

Figure 2 - Sphere of parallel lines passing through the same points to the North and South

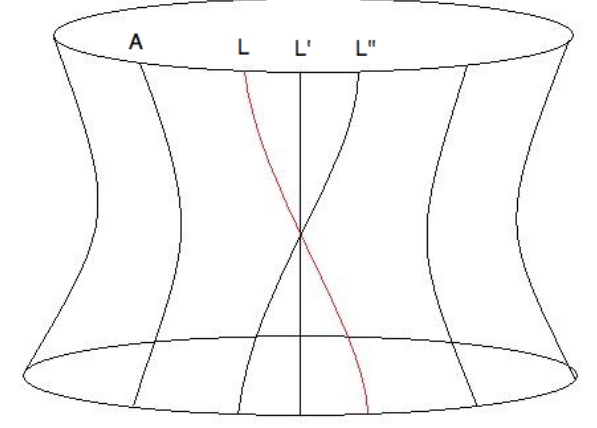

Figure 3 - Representation of parallel lines $\mathrm{L}, \mathrm{L}^{\prime}$ and $\mathrm{L}^{\prime \prime}$ passing through the same point

Figure 2 shows two parallel lines A and L from the same point in the North joining the same point un the South and, in Figure 3, three lines $L, L^{\prime}$ and $L^{\prime \prime}$ parallel to a single fourth line A, where all these three lines pass through the same point. In both cases the fifth postulate from Euclid is not respected. Thus the non-Euclidean geometries were born.

This intellectual development in geometry coincided with related scientific developments in other areas of knowledge. This is particularly the case in physics, which in the early 1920s saw the work of Albert Einstein, Marcel Grossman (1878-1936) and David Hilbert (1862-1943), based upon that of James Clerk Maxwell (1831-1879). These developments particularly concerned the move from the Galilean relativity principle, to the theories of special and general relativity. The theory of general relativity arose as a relativistic theory of gravitation, supplanting the theory of gravitation developed by Isaac Newton (16421727). Much the same applies regarding research by physicists such as Niels Bohr (18851962), Max Planck (1858-1947) and Erwin Schrödinger (1887-1961) during the first third of the twentieth century, all of whom questioned postulates from classical mechanics in the process of developing what would become quantum mechanics. 
These intellectual movements in physics are not, in itself, due to geometry, but we should note that the theory of general relativity by Einstein would have been impossible without the use of the differential geometry of Marcel Grossman (including work by Riemann). It would be better, then, to speak about the influence of geometry in physics - and in the same way, we may see it as having an influence in political economy (see the intense debate between John S. Mill (1806-1873) and William S. Jevons (1835-1882)). Hence, we may conclude, such inter-relationships in sciences were numerous at this time, and exceedingly fruitful. Rueff became one of the first French economists to adopt a relativist position and rank each theory according to this geometrical dichotomy ${ }^{4}$ :

As this ultimate reality is not given, we create it by enunciating a certain number of axioms and definitions which we make the premises of reasoning for deducing the empirical laws. Extending the theory thus constructed, we derive there from new laws which observation may either confirm or invalidate. In the first case, the logical theory remains true. We say that the created causes are also true and that the theory derived from them is a Euclidean theory. When the coincidence of the consequences with observed laws does not take place, the theory remains logical but it is no longer true. We say that it is a non-Euclidean theory. (1929 [1922]: 106)

Indeed Rueff only focuses on statistical relations between tools he designed. Rueff built his tools on elements that can be discussed but he was only interested in the interactions between these variables. That is why Rueff based his analysis on wholesale prices. Only accounts the movement of these prices compared with other variables such as the unemployment rate. Only accounts the link between all these variables. Here stands a conception of science and tools which is deeply influenced by advances in non-Euclidean geometry. Indeed it provides the idea that reality, the concrete observation of facts, is not essential anymore to produce knowledge. Hence this kind of geometry is not a priori visible in our plan. However, knowledge are produced and recognized by the scientific community. Then, the imperative of positive observation is no longer relevant in Rueff's views as it paves the way to a conception of reality as inaccessible. Hence "the confirmation of the fact, that real space is nothing more than a coherent system of definitions making the interpretations of observed appearances possible, is found in the existence of non-Euclidean geometries" (1929 [1922]: 32). This is upon this basis that Rueff builds its statistical tools. Then we shall analyse its conception of reality in order to better understand the scope of this approach.

\subsection{The reasoning machine and rational ego}

Rueff (1929 [1922]) allows that sciences can be divided into an empirical and a rational branch: the former collects facts, while the latter reasons on the basis of these facts in order to provide knowledge. Based on this division of labour, the sciences work together by observing the succession of facts and designing laws based upon these successions. The concept of science as it appears in Rueff's work is based on the intellectual approach known as constructivism. Inspired by Immanuel Kant (1724-1804), constructivism is the view that our picture of reality is not reality itself. Rueff holds that the human mind (the rational ego) builds up the sciences with the help of a specific set of tools (the reasoning machine) consisting of syntax, formal logic and mathematical analysis.

\footnotetext{
${ }^{4}$ Interestingly, Keynes uses the same dichotomy to show that his General Theory is a nonEuclidean one (1936: 16).
} 
Rueff bases his constructivist view of science upon two principles of human reason: identity and causality. The human mind cannot reason outside of these two principles, which are given a priori and ensure the good conduct of any reasoning. As an affirmation of the relationship between two things using the copula "is" (as in "A is B"), the principle of identity lies at the basis of deductive reasoning and mathematical induction. On the other hand, causality is based upon induction, and links things together in the way which governs the succession - or the concatenation, as Rueff put it - of external realities. Hence, in all being constructed in the same way by this reasoning machine, the sciences only differ according to their object:

We in nowise distinguish the mathematical sciences from the physical or natural, nor the social sciences. We claim that all sciences are of the same type, each comprising an experimental or observational branch which gleans the facts and extracts therefrom empirical laws, and a rational branch which "creates the cause."(1929 [1922]: 22)

The principle of identity allows for observation and deductive reasoning. It is the principle of the justification of mathematical science, paving the way to aggregative rules such as "what is true of the group is true of each individual component thereof" (Ibid., 6). When a thing is dependent on a theory, then, by syllogism, the facts of the same type depend on this theory: the human mind observes that an individual A is a man; he refers to the theory "all men are mortal" and concludes that the individual A is mortal. There is no real knowledge produced here, because our mind is only comparing a fact with a given theory. Here, then, stands the necessity of the principle of non-contradiction. Finally, these two principles underlie the rational and empirical branches of science. The first, necessarily subsequent to the second, is related to the creation of the causes, while the second concerns any given collection of facts that it aims to express under the form of laws.

Before submitting our thought to the principle of causality, it is necessary to formulate this thought by using syntax. Indeed, without using syntax our thought remains free-form and personal. In order to communicate ideas to others, a medium of exchange is necessary; it is this which gives rise to words, phrases and syntax in order to make the interchange of ideas possible. A thought, on this account, is expressed by a proposal that comprises a judgment submitted to the reasoning machine. Each proposal has to be very simple, and its content should appear immediately so as to ensure that it is free from internal contradictions. This principle of non-contradiction only applies to thought and not to syntax, while the latter only concerns the shape of the thought and not its substance. And a thought that does not obey this principle is not a human thought at all, as "it is a fact that only those judgements are 'human' which contain no contradiction [...] for beings such as ourselves, a contradictory judgment is inconceivable" (Ibid., 10-11).

In so far as there are false propositions, for instance, that "the Sun revolves around the Earth", this is due to the large number of characteristics in words that are not explicit. Based on the proposal that "a definition is a creative proposition which attaches certain characteristics to a word and by this fact gives it its existence" (Ibid., 13), Rueff argues that the definitions of "Sun", "Moon" and "Earth" are lacking characteristics such as heliocentrism, gravity, centrifugal force and other facts relevant to their interaction. This is why we should take care to keep propositions clear, especially in case of complex judgments. In fact, if a judgment is not compatible with the principle of causality, this is only due to a lack of clarity in our vocabulary.

Here stands the need for a method which enables us to link propositions so that they remain free from contradictions, in such a way as to deliver more complex reasoning. For instance, the reasoning in terms of mass exerting a force that makes a trajectory curved (in the case of gravitation) is certainly a complex judgment, but this is based upon demonstrated and 
observed principles. These constitute the axioms, "a priori judgments which we are free either to accept or reject" (Ibid., 12). In this respect, axioms enable us to discover new scientific laws: the reasoning machine as a relentless spiral of formal logic starts from two coherent propositions in such a way as to reach a third. Rueff states that this spiral creates nothing in itself, but only reveals reality, which nevertheless remains fundamentally unknown - inaccessible - to the human mind. Indeed, "nothing but a new definition or axiom, incorporated into a new system - i.e., united with a series of propositions already admitted or established, can create new mathematical 'facts' which then need only to be rendered "explicit"" (Ibid., 14). Once the reasoning is seen as a relentless spiral, it is upstream that we need to bring in new raw material. Rueff accordingly develops a method "which doesn't focus on the object itself, nor on the characteristics of the studied discipline, but rather on its linguistic formulation (Claassen 1967: 38).

The human mind can only work with tools, which are conventions such as methods of measurement or the axioms we have affirmed. In this, by referring to the principle of identity, the aim is to "render intelligible the system of our ever-changing sensations" (1929 [1922]: 7), but it follows that the human mind is what really creates connections of causation. For instance, gravity is only the cause that creates the following effects: the "Moon revolves around the Earth," and "the Earth revolves around the Sun". Therefore "the Law of Causality, which seems to be the expression of physical reality independent of ourselves, owes its existence merely to the effort of our mind to impose that law upon the world" (Ibid., 10). Hence the human mind is not passive, as it apprehends, through this principle of causality, a constant succession of appearances. Prior to the rational branch, the empirical one observes sequences of appearances that are generalized into laws of succession: but this doesn't concern the law of causality, as causes are entirely created by the needs of the human spirit to conform human thought to an appearance of reality:

The role of the human mind is not purely passive in the observation of the laws constituting the empirical branch of science. Man does more than merely record appearances. He determines them to a great extent [...] To say that the empirical laws of our world have existence in themselves is an affirmation without any meaning. (Ibid., 39)

Thus, according to the early Rueff, all science creates causes in order to find, via deduction, laws that connect sensory experiences. These views on science are explained by the discovery of non-Euclidean geometry. This profoundly influenced his reasoning on science in general and on political economy in particular. Thus, Rueff defines his variables (unemployment, price, wage) and tries to combine them in order to set out his reasoning. This paves the way to political economy becoming seen as a statistical science (which is the title of his article of 1925a, see also 1961 [1929]). Here we clearly see the links with geometry, as Rueff only deals with the relation between variables and looks for a succession of facts. More precisely, in his work it is possible to identify some elements which prefigure econometrics. Indeed, his work is based upon a permanent relationship between the level of unemployment and wage/price ratio, i.e. a correlation, one of the main purposes of the econometric field. A correlation - a term drawn from biology - would be defined as the intensity in the statistical sense of a link between variables, or numerical statistics, and this is exactly what provides the basis of Rueff's analysis. Obviously, Rueff is still far from the linear regression models and other affine relations that would emerge in future decades, but we must admit that here lie the roots of econometrics. Moreover, having established this strong correlation, Rueff looks for a causal link. Such a link may exist between these variables based upon work by Stamp, consisting in a computing the correlation coefficient between the two variables studied: 
This was a quite exceptional correlation in its permanency, and such a correlation permits an affirmation that the two elements under consideration - unemployment and the wage/price ratio - were either dependent on one another due to a causal relationship, or were dependent on a third factor which would be the common cause of variations. (1931a: 213)

\section{Concluding remarks}

The study of the relationship between unemployment and the wage/price ratio shows a clear succession of facts. Unemployment in England between the two World Wars is due to the viscosity of this ratio. This is why Rueff is often seen as a liberal who advocates pay cuts and disregards the working classes: but this is a mistake. No matter the level of wage, the sole factor which needs to be accounted for is the way wages are determined, which has to be free and in perfect accord with the rules of the liberal market. This is based upon a structure of reasoning that recalls the axiomatic method of geometry and which demonstrates that there is no need to observe the sensible world to practice science.

The result of these lessons learned from non-Euclidean geometry is that we can study variables and economic quantities (unemployment, wages, prices). The sensible world no longer has a monopoly on the creation of knowledge. It is possible to study variables and their succession, and provide scientific laws upon this basis.

In the end, the conception of reality as it appears in Rueff's work is rather sceptical of the capacity of the human mind. Our minds, being unable to access the real, only create appearances of reality and not reality itself. Where does the production of knowledge come from? How can the human mind formulate any idea? Yet even if reality is inaccessible in itself, as Rueff thinks, it is still possible to build knowledge in such a way as to approach it as closely as possible. The human mind has access to the products of the interaction between thought and its environment, not to the environment itself. In this, language, as well as the reasoning machine and rational ego, prove to be indispensable tools.

\section{References}

- Beveridge, W.-H., 1909, Unemployment, a Problem of Industry, London: Longman, Green and Co.

- Chivvis, C., 2010, The Monetary Conservative: Jacques Rueff and Twentieth-century free market thought, De Kalb: Northern Illinois University Press.

- Claassen, E.-M., 1967, "Jacques Rueff comme philosophe des sciences", pp. 37-62, in Claassen, E.-M., 1967, Les Fondements Philosophiques des Systèmes Economiques, Textes de Jacques Rueff et essais rédigés en son honneur, Paris: Payot.

- Euclid, 2007, Euclid's Elements of Geometry, The Greek text of J.L. Heiberg (18831885) from Euclidis Elementa, edidit et Latine interpretatus est I.L. Heiberg, in aedibus B.G. Teubneri, 1883-1885, Edited and provided with a modern English translation, by Richard Fitzpatrick, http://www.math.unipd.it/

- Fisher, I., 1926, "Les relations statistiques entre le chômage et le mouvements des prix", Revue Internationale du Travail, 12(6): 846-853.

- Frobert L., 2010, "Conventionalism and liberalism in Jacques Rueff's early works (1922 to 1929)", European Journal of History of Economic Thought, 17(3): 439-470.

- Hick, J., 1932, The Theory of Wages, London: Mac Millan.

- Keynes, J.-M., 1929a, "The German transfer problem”, The Economic Journal, 39: 117. 
- 1929b, "The reparations problem: a discussion II. A rejoinder", The Economic Journal, 39: 179-182.

- 1929c, "Mr. Keynes' Views on the Transfer Problem: A Reply", The Economic Journal, 39: 404-408.

- 1936, The General Theory of Employment, Interest and Money, London: Mac Millan.

- 1939, "Relative movements of real wages and output", The Economic Journal, 49: 34-51.

- Mundell, R., 1973, "The monetary consequences of Jacques Rueff”, The Journal of Business, 46(3): 384-395.

- Rueff, J., 1929[1922], From the Physical to the Social Sciences, Transl. H. Green, London: Oxford University Press.

- 1925a, "L'économie politique, science statistique", Revue de Métaphysique et de Morale, 10: 475-487.

- 1925b, "Les variations du chômage en Angleterre", Revue Politique et Parlementaire, 32(6): 425-437.

- 1926, "Chômage et salaires réel en Angleterre dans la période 1919-1925, Séance de la Société d'Économie Sociale du 14 décembre 1925", La Réforme Sociale, 2: 49-73.

- 1927, Théorie des phénomènes monétaires, in Rueff, J., 1979, Euvres complètes, II, Théorie monétaire, 1, Paris: Plon.

- 1961 [1929], "La statistique, instrument de la connaissance", Journal de la Société Statistique de Paris, 102: 220-224.

- 1931a, "L'Assurance chômage cause du chômage permanent", Revue d'Économie Politique, 45: 211-251.

- 1931b, "L'assurance chômage, cause du chômage permanent", pp. 300-331, in Académie des Science Morales et Politiques, 1931, Séances et travaux de l'Académie des sciences morales et politiques : Compte rendu, $2^{\mathrm{e}}$ semestre, Paris: Alcan.

- 1935, "Préface", pp. 7-14, in Robbins, L., 1935, La grande dépression, 1929-1934, Payot: Paris.

- 1977, De l'aube au crépuscule, Autobiographie, Euvres complètes I, Paris: Plon.

- Pays, B., 1991, Libérer la Monnaie: les Contributions Monétaires de Mises, Rueff et Hayek, Paris: PUF.

- $\quad$ Pigou A.-C., 1920, The Economic of Welfare, London: Mac Millan.

- 1927, "Wage policy and unemployment", The Economic Journal, 37: 355-368.

- Poincaré, H., 1982 [1902], Science and Hypothesis, Transl. W.-J.-G., New York:

Dover.

- 1958 [1905], The Value of Science, Transl. G. Halsted, New York: Dover. 


\section{Tables}

\begin{tabular}{|c|c|c|c|c|c|c|c|c|c|}
\hline & & $\begin{array}{c}\text { Wages } \\
(1913 \\
\text { base } \\
100)\end{array}$ & $\begin{array}{c}\text { Variations of } \\
\text { wages (\%) }\end{array}$ & $\begin{array}{c}\text { Prices } \\
(1913 \\
\text { base } \\
100)\end{array}$ & $\begin{array}{l}\text { Jariations of } \\
\text { prices (\%) }\end{array}$ & $\begin{array}{l}\text { Wage/Pr } \\
\text { ice ratio }\end{array}$ & $\begin{array}{l}\text { Variations of } \\
\text { wage/price } \\
\text { ratio (\%) }\end{array}$ & $\begin{array}{l}\text { Unem- } \\
\text { ployment } \\
\text { rate }(\%)\end{array}$ & $\begin{array}{l}\text { Variations } \\
\text { of unem- } \\
\text { ployment } \\
\text { rate (pts) }\end{array}$ \\
\hline \multirow{4}{*}{1919} & 1 & 207 & \multirow{9}{*}{$+33,4$} & 249 & \multirow{6}{*}{$+30,1$} & 0.831 & \multirow{5}{*}{$-10,1$} & 2.7 & \multirow{6}{*}{$-1,6$} \\
\hline & 2 & 209 & & 242 & & 0.863 & & 2.2 & \\
\hline & 3 & 216 & & 258 & & 0.837 & & 1.9 & \\
\hline & 4 & 221 & & 288 & & 0.767 & & 2.9 & \\
\hline \multirow{4}{*}{1920} & 1 & 231 & & 309 & & 0.747 & & 1.9 & \\
\hline & 2 & 250 & & 324 & & 0.771 & \multirow{8}{*}{$+72,1$} & 1.1 & \\
\hline & 3 & 267 & & 314 & \multirow{6}{*}{$-44,6$} & 0.850 & & 1.7 & \multirow{4}{*}{$+19,2$} \\
\hline & 4 & 273 & & 284 & & 0.961 & & 5.0 & \\
\hline \multirow{4}{*}{1921} & 1 & 276 & & 227 & & 1.251 & & 8.5 & \\
\hline & 2 & 268 & \multirow{6}{*}{$-29,5$} & 201 & & 1.333 & & 20.9 & \\
\hline & 3 & 244 & & 190 & & 1.284 & & 16 & \multirow{12}{*}{$-8,8$} \\
\hline & 4 & 228 & & 174 & & 1.310 & & 16 & \\
\hline \multirow{4}{*}{1922} & 1 & 215 & & 162 & \multirow{16}{*}{$-5,6$} & 1.327 & & 16.5 & \\
\hline & 2 & 202 & & 160 & & 1.262 & \multirow{7}{*}{$-19,6$} & 16.4 & \\
\hline & 3 & 189 & & 157 & & 1.203 & & 14.5 & \\
\hline & 4 & 178 & & 156 & & 1.141 & & 14.1 & \\
\hline \multirow{4}{*}{1923} & 1 & 177 & & 158 & & 1.120 & & 13 & \\
\hline & 2 & 177 & & 160 & & 1.106 & & 11.2 & \\
\hline & 3 & 174 & & 156 & & 1.115 & & 11.3 & \\
\hline & 4 & 173 & & 161 & & 1.014 & & 10.4 & \\
\hline \multirow{4}{*}{1924} & 1 & 174 & & 166 & & 1.048 & \multirow{8}{*}{$+12,2$} & 8.3 & \\
\hline & 2 & 177 & $+1,1$ & 164 & & 1.079 & & 7.2 & \\
\hline & 3 & 179 & & 165 & & 1.084 & & 8 & \multirow{6}{*}{$+3,1$} \\
\hline & 4 & 179 & & 170 & & 1.052 & & 8.8 & \\
\hline \multirow{4}{*}{1925} & 1 & 181 & & 169 & & 1.071 & & 9.1 & \\
\hline & 2 & 181 & & 160 & & 1.138 & & 10.6 & \\
\hline & 3 & 180 & & 157 & & 1.153 & & 11.3 & \\
\hline & 4 & 180 & & 153 & & 1.176 & & 11.1 & \\
\hline
\end{tabular}

Table n. 1: Variations of prices, wages, wage/price ratio, and unemployment rate. Figures from Rueff (1925b). 


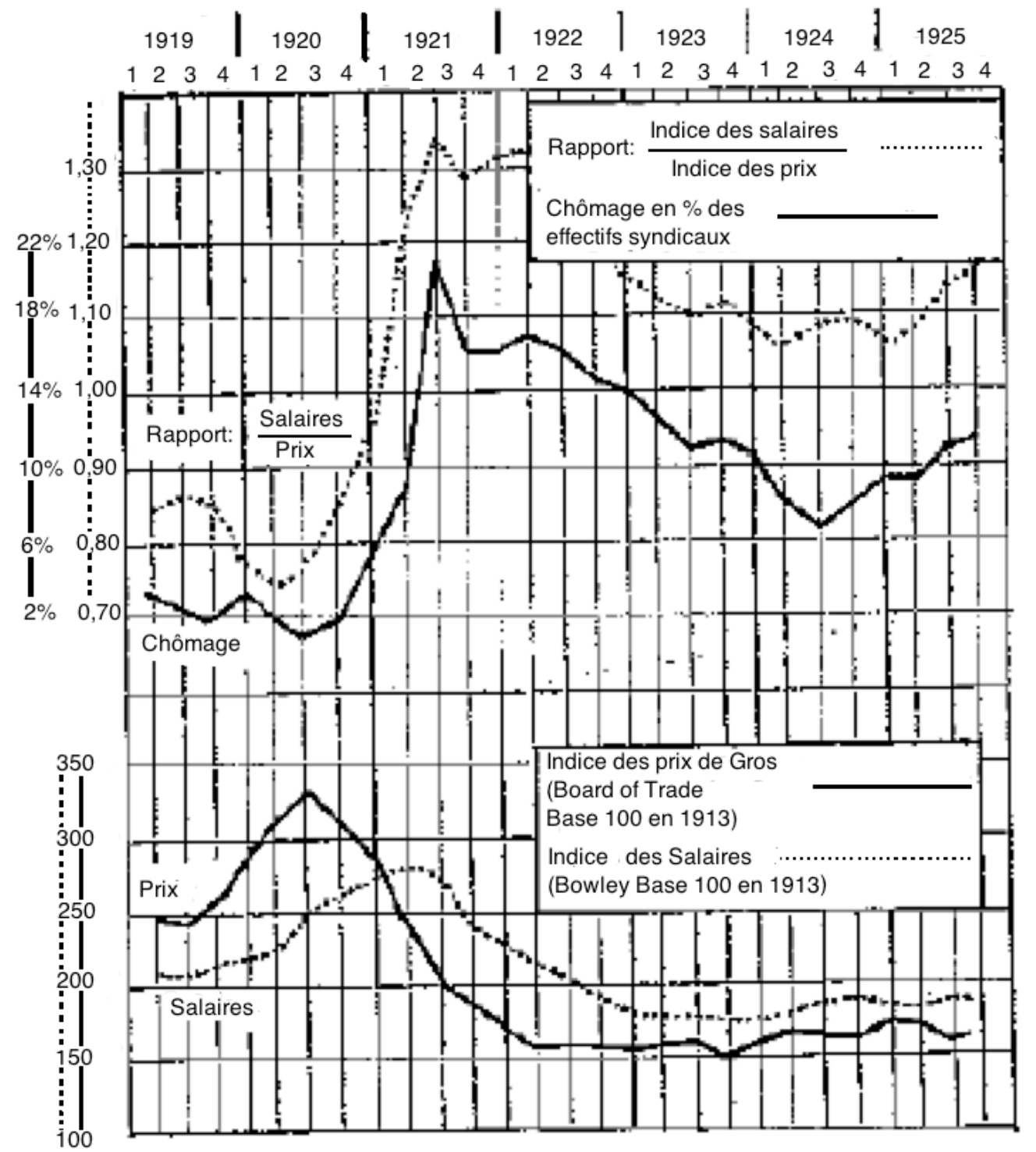

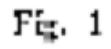

Diagram n. 1: "Les variations du chômage en Angleterre (1919-1925)" in Rueff, 1925b: 431. 


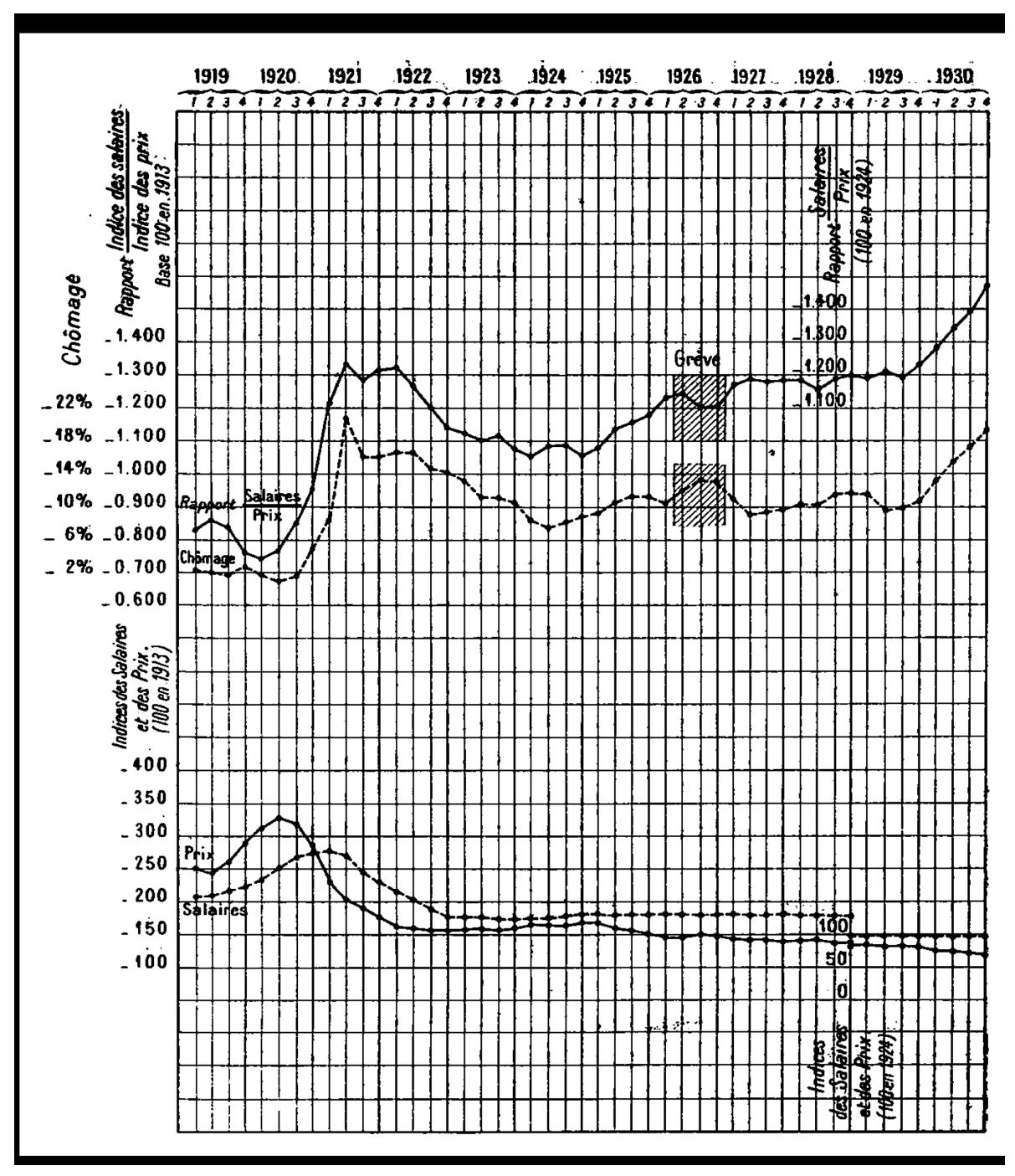

Diagram n. 2: Untitled diagram from the article published anonymously by Rueff in Rueff, 1931b: 301. 